\title{
EXOGENOUS ASCORBIC ACID IMPROVES DEFENCE RESPONSES OF SUNFLOWER (HELIANTHUS ANNUUS) EXPOSED TO MULTIPLE STRESSES
}

\author{
ARMAGan KaYA* \\ Basic Concepts of Engineering, Faculty of Engineering, Alanya Alaaddin Keykubat University, \\ Alanya, Antalya, Turkey
}

(Received: April 3, 2017, accepted: May 22, 2017)

\begin{abstract}
Ascorbic acid is an important antioxidant that plays role both on growth and development and also stress response of the plant. The purpose of this study was to determine the effect of ascorbate on physiological and biochemical changes of sunflower that was exposed to multiple stresses. Chlorophyll and carotenoid contents decreased and glutathione, ascorbate and malondialdehyde contents as well as antioxidant enzyme activities increased for sunflower plant that was exposed to $50 \mathrm{mM} \mathrm{NaCl}$ and pendimethalin at different concentrations. These changes were found to be more significant in groups simultaneously exposed to both stress factors. While malondialdehyde content decreased, chlorophyll, carotenoid, ascorbate, glutathione contents and antioxidant enzyme activities increased in plants treated exogenously with ascorbate, compared to the untreated samples. According to the findings of our study; compared to individual stress, the effect of stress is more pronounced in sunflower exposed to multiple stresses, and treatment with exogenous ascorbate reduces the negative effects of stress.
\end{abstract}

Keywords: Ascorbate - sunflower - pendimethalin - $\mathrm{NaCl}$ - antioxidant

\section{INTRODUCTION}

Plants usually exposed to numerous stress factors simultaneously in their natural environment. Abiotic stresses (salinity, drought, high temperature, pesticides etc.) cause changes in physiological and biochemical functions of plants [21]. Salt stress is one of the abiotic stress factors which negatively affects plant growth and development [10]. It is known that changes occur at pigment content, lipid peroxidation, prolin content and antioxidant activity of sunflower exposed to salinity [20, 37]. In addition to salinity, weeds formation in sunflower growing areas has become an important problem. Different herbicides are used to inhibit weeds. Pendimethalin is a herbicide used commonly for fight against weeds with narrow and broad leaves especially in areas where cotton, sunflower and vegetables are grown. Pendimethalin injures weeds by binding to tubilin and disrupts the mitotic sequence $[6,41]$.

\footnotetext{
*E-mail address: armagan-kaya@hotmail.com
} 
Abiotic stresses increase production of reactive oxygen species (ROS) in plants. The ROS are highly reactive and toxic and thus lead to damage to proteins, lipids, carbohydrates and DNA which ultimately results in oxidative stress [16]. Plants have developed various tolerance mechanisms in order to cope with abiotic stresses. Ascorbate-glutathione (AsA-GSH) pathway plays an important role in protecting cell against ROS that are produced by stress. AsA-GSH pathway includes both enzymatic (such as ascorbate peroxidase, APX; glutathione reductase, GR; glutathione S-transferase, GST) and non-enzymatic (including ascorbic acid, AsA and glutathione, GSH) antioxidants These antioxidants play a vital role in plant defence responses and help the plant survive $[15,30]$.

Exogenous treatment of various antioxidant compounds increase stress tolerance of plants by inducing antioxidant activity [8, 25, 28]. Ascorbate (AsA) known as L-ascorbic acid or vitamin $\mathrm{C}$ is a multi-functional compound in both plants and animals. AsA, which plays an important role in stress defense and that is an important compound of ascorbate-glutation cycle, plays also role on cell division of plants, cell wall metabolism, root development, shoot apical meristem formation and photosynthesis $[5,16]$. It is known that exogenous treatment of the AsA regulate antioxidant responses in plants under salt stress [8,25]. With this regard as suggested by Sivaci et al. for chilling stress for $S$. muricatum, Abbasi and Faghani for salt stress in T. aestivum, Verma et al. for metal stress in B. Juncea, it was tested and found to have reduced stress effect of the AsA pre-treatment $[1,38,43]$.

The goal of this study is to determine defense responses of sunflower plant exposed to herbicide and salinity stresses both separately and simultaneously and to investigate the effects of exogenous AsA application (as pre-sowing) on these changes in sunflower plants.

\section{MATERIAL AND METHODS}

\section{Plant materials and treatments}

In this study, the pendimethalin herbicide was provided by "Basf". ES Novamis CL was used as sunflower seed. The seeds were planted after a portion of the plants was incubated for six hours in distillated water, whereas another portion was incubated for six hours in a $100 \mu \mathrm{g} / \mathrm{L}$ ascorbic acid solution. Before germination of seeds, only pendimethalin $(8,16,32 \mathrm{mM})$ in some portion of pot, only $50 \mathrm{mM} \mathrm{NaCl}$ to some other portion of the pot and both $50 \mathrm{mM} \mathrm{NaCl}$ and pendimethalin $(8,16,32 \mathrm{mM})$ together to the remaining portion of the pot were applied. Plants were grown in triplicate at pots containing peat under conditions having an average temperature of $28{ }^{\circ} \mathrm{C}$ and an average humidity of $60 \%$ in climate room. The leaves were gathered at about $21^{\text {st }}$ day of growth and were stored at $-80{ }^{\circ} \mathrm{C}$ freezer for analysis. 


\section{Physiological and biochemical analyses}

Extraction and purification of the pigments were made according to De Kok and Graham [11]. Absorbance values of the samples were measured at 662, 645 and 470 $\mathrm{nm}$ according to Lichtenthaler and Welburn [27]. For determination of antioxidant activity, extraction of plant leaves were made according to Andrews [4]. Ascorbate peroxidase (APX) activity was determined according to Nakano and Asada [34]. The glutathione S-transferase (GST) activity was analyzed according to Habig et al. [17]. The glutathione reductase (GR) activity was performed according to Carlberg and Mannervik [9]. The glutathione (GSH) content was determined according to Akerboom and Sies [2]. The ascorbate (AsA) content was analysed according to Mukherjee and Choudhuri [33]. The malondialdehyde (MDA) content was analyzed according to Heath and Packer [19].

Statistical analysis was performed using the SPSS 17.0 software. Duncan's method [12] and " $t$ "-tests were used to determine the differences between averages and $p<0.05$ was considered statistically significant in the analyses.

\section{RESULTS}

\section{Total chlorophyll and carotenoids contents}

Total chlorophyll content for the plants not pretreated with AsA decreased compared to the control groups while it increased in plants treated with AsA $(p<0.05)$. The total chlorophyll content decreased to a higher degree in the pendimethalin combined with $\mathrm{NaCl}$-treated plants compared to separately treated groups $(p<0.05)$. The highest total chlorophyll content for the plants treated with AsA was found in the $32 \mathrm{mM}$ pendimethalin treated group as $13.58 \mu \mathrm{g} \mathrm{g}^{-1}$ (FW). Exogenous AsA treatment increased the total chlorophyll content in the stress groups (Table 1).

Carotenoid content for the plants not pretreated with AsA decreased compared to the control groups while it increased for plants treated with AsA $(p<0.05)$. The highest carotenoid content for the plants treated with AsA was found in the $50 \mathrm{mM}$ $\mathrm{NaCl}+32 \mathrm{mM}$ pendimethalin treated group as $6.81 \mu \mathrm{g} \mathrm{g}^{-1}(\mathrm{FW})$. Exogenous AsA treatment increased the carotenoid content both in the control and stressed groups (Table 1).

\section{AsA content}

The AsA content increased in the plants, regardless of AsA treatment, in the stress groups, compared to the control groups $(p<0.05)$. The highest AsA content for the plants pretreated with AsA was found in the $50 \mathrm{mM} \mathrm{NaCl}+32 \mathrm{mM}$ pendimethalin treated group as $0.57 \mu \mathrm{g} \mathrm{g}^{-1} \mathrm{FW}$. Exogenous AsA treatment increased the endogenous AsA content in the control and stressed groups $(p<0.05)$ (Table 2). 
Table 1

Changes in total chlorophyll and carotenoids contents $\left(\mu \mathrm{g} \mathrm{g}^{-1} \mathrm{FW}\right)$ in sunflower leaves exposed to $\mathrm{NaCl}$ and pendimethalin stresses

\begin{tabular}{|c|c|c|c|c|}
\hline \multirow{2}{*}{ Groups } & \multicolumn{2}{|c|}{$\begin{array}{l}\text { Total chlorophyll content } \\
\left(\mu \mathrm{g} \mathrm{g}^{-1} \mathrm{FW}\right)\end{array}$} & \multicolumn{2}{|c|}{$\begin{array}{l}\text { Carotenoids content } \\
\qquad\left(\mu \mathrm{g} \mathrm{g}^{-1} \mathrm{FW}\right)\end{array}$} \\
\hline & $\operatorname{AsA}(-)$ & $\operatorname{AsA}(+)$ & $\operatorname{AsA}(-)$ & AsA (+) \\
\hline Control (0) & $\mathrm{A} 11.29 \pm 0.1^{\mathrm{a}}$ & $\mathrm{B} 8.43 \pm 0.2^{\mathrm{f}}$ & $\mathrm{B} 2.17 \pm 0.01^{\mathrm{a}}$ & A $3.42 \pm 0.02^{\mathrm{g}}$ \\
\hline $8 \mathrm{mM}$ pendimethalin & $\mathrm{B} 10.06 \pm 0.1^{\mathrm{b}}$ & $\mathrm{A} 10.68 \pm 0.1^{\mathrm{d}}$ & $\mathrm{B} 1.97 \pm 0.02^{\mathrm{b}}$ & A $3.77 \pm 0.01^{\mathrm{f}}$ \\
\hline $16 \mathrm{mM}$ pendimethalin & $\mathrm{B} 9.85 \pm 0.1^{\mathrm{c}}$ & $\mathrm{A} 11.60 \pm 0.1^{\mathrm{c}}$ & $\mathrm{B} 1.60 \pm 0.02^{\mathrm{d}}$ & $\mathrm{A} 4.01 \pm 0.03^{\mathrm{e}}$ \\
\hline $32 \mathrm{mM}$ pendimethalin & B $9.80 \pm 0.1^{\mathrm{c}}$ & $\mathrm{A} 13.58 \pm 0.1^{\mathrm{a}}$ & $\mathrm{B} 1.90 \pm 0.03^{\mathrm{b}}$ & $\mathrm{A} 4.44 \pm 0.02^{\mathrm{c}}$ \\
\hline $50 \mathrm{mM} \mathrm{NaCl}$ & A $9.04 \pm 0.2^{\mathrm{d}}$ & $\mathrm{A} 9.40 \pm 0.2^{\mathrm{e}}$ & $\mathrm{B} 1.71 \pm 0.03^{\mathrm{c}}$ & A3.81 $\pm 0.01^{\mathrm{f}}$ \\
\hline $\begin{array}{l}50 \mathrm{mM} \mathrm{NaCl}+8 \mathrm{mM} \\
\text { pendimethalin }\end{array}$ & $\mathrm{B} 8.43 \pm 0.1^{\mathrm{e}}$ & $\mathrm{A} 9.47 \pm 0.1^{\mathrm{e}}$ & $\mathrm{B} 1.63 \pm 0.01^{\mathrm{d}}$ & $\mathrm{A} 4.17 \pm 0.03^{\mathrm{d}}$ \\
\hline $\begin{array}{l}50 \mathrm{mM} \mathrm{NaCl}+16 \mathrm{mM} \\
\text { pendimethalin }\end{array}$ & B $6.70 \pm 0.2^{\mathrm{f}}$ & $\mathrm{A} 11.08 \pm 0.2^{\mathrm{d}}$ & $\mathrm{B} 1.39 \pm 0.02 \mathrm{e}$ & A5. $11 \pm 0.01^{b}$ \\
\hline $\begin{array}{l}50 \mathrm{mM} \mathrm{NaCl}+32 \mathrm{mM} \\
\text { pendimethalin }\end{array}$ & $\mathrm{B} 5.86 \pm 0.3^{\mathrm{g}}$ & $\mathrm{A} 12.35 \pm 0.2^{\mathrm{b}}$ & $\mathrm{B} 1.07 \pm 0.01^{\mathrm{f}}$ & $\mathrm{A} 6.81 \pm 0.01^{\mathrm{a}}$ \\
\hline
\end{tabular}

The different lower-case letters marked groups are significantly different from each other $(p<0.05)$ among different concentration of $\mathrm{NaCl}$ and pendimethalin according to Duncan's test. The different capital-case letters mark significant difference between the AsA $(+)$ and AsA $(-)$ samples $(p<0.05)$ of each concentration (of control and stress groups) according to independent samples " $t$ "--test.

Table 2

Changes in total AsA and GSH contents in sunflower leaves exposed to $\mathrm{NaCl}$ and pendimethalin stresses

\begin{tabular}{|c|c|c|c|c|}
\hline \multirow{2}{*}{ Groups } & \multicolumn{2}{|c|}{$\begin{array}{l}\text { Ascorbate content } \\
\left(\mathrm{mg} \mathrm{g}^{-1} \mathrm{FW}\right)\end{array}$} & \multicolumn{2}{|c|}{$\begin{array}{l}\text { GSH content } \\
\left(\mathrm{mg} \mathrm{g}^{-1} \mathrm{FW}\right)\end{array}$} \\
\hline & AsA (-) & AsA (+) & AsA (-) & AsA (+) \\
\hline Control (0) & B $0.03 \pm 0.004 \mathrm{~g}$ & $\mathrm{~A} 0.11 \pm 0.001 \mathrm{~g}$ & B $0.39 \pm 0.01^{\mathrm{f}}$ & A $0.48 \pm 0.02^{\mathrm{e}}$ \\
\hline $8 \mathrm{mM}$ pendimethalin & B $0.05 \pm 0.008^{f}$ & A $0.15 \pm 0.003^{\mathrm{f}}$ & B $0.41 \pm 0.01^{\mathrm{e}}$ & $\mathrm{A} 0.62 \pm 0.03^{\mathrm{c}}$ \\
\hline $16 \mathrm{mM}$ pendimethalin & B $0.11 \pm 0.002^{\mathrm{d}}$ & $\mathrm{A} 0.17 \pm 0.002^{\mathrm{e}}$ & $\mathrm{B} 0.49 \pm 0.02^{\mathrm{d}}$ & A0.67 $\pm 0.02^{\mathrm{c}}$ \\
\hline $32 \mathrm{mM}$ pendimethalin & B $0.12 \pm 0.007^{d}$ & $\mathrm{~A} 0.29 \pm 0.001^{\mathrm{c}}$ & B0.57 $\pm 0.01^{b}$ & $\mathrm{~A} 0.79 \pm 0.01^{\mathrm{a}}$ \\
\hline $50 \mathrm{mM} \mathrm{NaCl}$ & B $0.09 \pm 0.003^{\mathrm{e}}$ & $\mathrm{A} 0.21 \pm 0.001^{\mathrm{d}}$ & $\mathrm{B} 0.51 \pm 0.01^{\mathrm{d}}$ & $\mathrm{A} 0.57 \pm 0.01^{\mathrm{d}}$ \\
\hline $\begin{array}{l}50 \mathrm{mM} \mathrm{NaCl}+8 \mathrm{mM} \\
\text { pendimethalin }\end{array}$ & B $0.17 \pm 0.004^{\mathrm{c}}$ & $\mathrm{A} 0.29 \pm 0.003^{\mathrm{c}}$ & $\mathrm{B} 0.65 \pm 0.02^{\mathrm{a}}$ & $\mathrm{A} 0.71 \pm 0.01^{\mathrm{b}}$ \\
\hline $\begin{array}{l}50 \mathrm{mM} \mathrm{NaCl}+16 \mathrm{mM} \\
\text { pendimethalin }\end{array}$ & B $0.24 \pm 0.001^{b}$ & $\mathrm{~A} 0.36 \pm 0.004^{\mathrm{b}}$ & $\mathrm{B} 0.63 \pm 0.01^{\mathrm{a}}$ & $\mathrm{A} 0.72 \pm 0.01^{\mathrm{b}}$ \\
\hline $\begin{array}{l}50 \mathrm{mM} \mathrm{NaCl}+32 \mathrm{mM} \\
\text { pendimethalin }\end{array}$ & B $0.31 \pm 0.007 \mathrm{a}$ & $\mathrm{A} 0.57 \pm 0.005^{\mathrm{a}}$ & B $0.53 \pm 0.01^{\mathrm{c}}$ & $\mathrm{A} 0.64 \pm 0.02^{\mathrm{c}}$ \\
\hline
\end{tabular}

The different lower-case letters marked groups are significantly different from each other $(p<0.05)$ among different concentration of $\mathrm{NaCl}$ and pendimethalin according to Duncan's test. The different capital-case letters mark significant difference between the AsA $(+)$ and AsA $(-)$ samples $(p<0.05)$ of each concentration (of control and stress groups) according to independent samples " $t$ "--test. 


\section{GSH content}

The GSH content increased in the stress groups compared to the control groups both in the AsA pre-treated and non-treated plants $(p<0.05)$. The highest GSH content was found as $0.79 \mathrm{mg} \mathrm{g}^{-1} \mathrm{FW}$ in the $32 \mathrm{mM}$ pendimethalin treated group in the plants pre-treated with AsA. Exogenous AsA treatment increased the GSH content in all plants $(p<0.05)$ (Table 2).

\section{The activities of antioxidant enzymes}

The GST activity increased in the plants, regardless of AsA treatment, in the stress groups compared to the control groups $(p<0.05)$. The highest GST activity was found in the $16 \mathrm{mM}$ pendimethalin treated group as $1.19 \mu \mathrm{mol} \mathrm{min}^{-1} \mathrm{mg}^{-1}$ protein in the AsA treated plants. Exogenous AsA treatment increased the GST activity in the control and stress groups $(p<0.05)$ (Table 3$)$.

The GR activity increased in the plants, regardless of AsA treatment, in the stress groups compared to the control groups $(p<0.05)$. The highest GR activity was found in the $50 \mathrm{mM} \mathrm{NaCl}+32 \mathrm{mM}$ pendimethalin treated group as $0.89 \mu \mathrm{mol} \mathrm{min}^{-1} \mathrm{mg}^{-1}$ protein in the AsA treated plants. Exogenous AsA treatment increased the GR activity in in all plant $(p<0.05)$ (Table 3$)$.

In both AsA treated and non-treated plants, the APX activity increased in the stress groups compared to the control groups. The highest APX activity for the plants pre-

Table 3

Changes in GST and GR activities in sunflower leaves exposed to $\mathrm{NaCl}$ and pendimethalin stresses

\begin{tabular}{|c|c|c|c|c|}
\hline \multirow[t]{2}{*}{ Groups } & \multicolumn{2}{|c|}{$\begin{array}{c}\text { GST activity } \\
\left(\mu \mathrm{mol} \mathrm{min}^{-1} \mathrm{mg}^{-1} \text { protein }\right)\end{array}$} & \multicolumn{2}{|c|}{$\begin{array}{c}\text { GR activity } \\
\left(\mu \mathrm{mol} \mathrm{min} \mathrm{mg}^{-1} \mathrm{mg}^{-1} \text { protein }\right)\end{array}$} \\
\hline & $\operatorname{AsA}(-)$ & $\operatorname{AsA}(+)$ & $\operatorname{AsA}(-)$ & $\operatorname{AsA}(+)$ \\
\hline Control (0) & $\mathrm{B} 0.20 \pm 0.01^{\mathrm{d}}$ & $\mathrm{A} 0.79 \pm 0.01^{\mathrm{d}}$ & B $0.25 \pm 0.01^{\mathrm{e}}$ & $\mathrm{A} 0.52 \pm 0.01^{\mathrm{e}}$ \\
\hline $8 \mathrm{mM}$ pendimethalin & B $0.43 \pm 0.02^{c}$ & $\mathrm{~A} 0.88 \pm 0.03^{\mathrm{c}}$ & B $0.39 \pm 0.02^{d}$ & A $0.71 \pm 0.02^{\mathrm{c}}$ \\
\hline $16 \mathrm{mM}$ pendimethalin & B $0.57 \pm 0.04^{b}$ & $\mathrm{~A} 1.19 \pm 0.01^{\mathrm{a}}$ & B $0.39 \pm 0.01^{d}$ & $\mathrm{~A} 0.64 \pm 0.01^{\mathrm{d}}$ \\
\hline $32 \mathrm{mM}$ pendimethalin & B $0.24 \pm 0.01^{\mathrm{e}}$ & A $0.64 \pm 0.03^{\mathrm{e}}$ & B $0.46 \pm 0.02^{\mathrm{c}}$ & A $0.57 \pm 0.01^{\mathrm{f}}$ \\
\hline $50 \mathrm{mM} \mathrm{NaCl}$ & B $0.59 \pm 0.01^{\mathrm{b}}$ & A $0.92 \pm 0.01^{\mathrm{c}}$ & B $0.46 \pm 0.03^{\mathrm{c}}$ & A $0.75 \pm 0.03^{\mathrm{c}}$ \\
\hline $\begin{array}{l}50 \mathrm{mM} \mathrm{NaCl}+8 \mathrm{mM} \\
\text { pendimethalin }\end{array}$ & $\mathrm{B} 0.88 \pm 0.03^{\mathrm{a}}$ & $\mathrm{A} 0.97 \pm 0.02^{\mathrm{b}}$ & $\mathrm{B} 0.60 \pm 0.02^{\mathrm{a}}$ & $\mathrm{A} 0.85 \pm 0.01^{\mathrm{b}}$ \\
\hline $\begin{array}{l}50 \mathrm{mM} \mathrm{NaCl}+16 \mathrm{mM} \\
\text { pendimethalin }\end{array}$ & $\mathrm{B} 0.80 \pm 0.04^{\mathrm{a}}$ & $\mathrm{A} 1.11 \pm 0.01^{\mathrm{b}}$ & $\mathrm{B} 0.64 \pm 0.01^{\mathrm{a}}$ & A $0.88 \pm 0.01^{\mathrm{a}}$ \\
\hline $\begin{array}{l}50 \mathrm{mM} \mathrm{NaCl}+32 \mathrm{mM} \\
\text { pendimethalin }\end{array}$ & B $0.40 \pm 0.01^{\mathrm{c}}$ & $\mathrm{A} 1.09 \pm 0.01^{\mathrm{b}}$ & B $0.55 \pm 0.02^{b}$ & $\mathrm{~A} 0.89 \pm 0.01^{\mathrm{a}}$ \\
\hline
\end{tabular}

The different lower-case letters marked groups are significantly different from each other $(p<0.05)$ among different concentration of $\mathrm{NaCl}$ and pendimethalin according to Duncan's test. The different capital-case letters mark significant difference between the AsA $(+)$ and AsA $(-)$ samples $(p<0.05)$ of each concentration (of control and stress groups) according to independent samples " $t$ "--test. 
Table 4

Changes in APX activity and MDA content in sunflower leaves exposed to $\mathrm{NaCl}$ and pendimethalin stresses

\begin{tabular}{|c|c|c|c|c|}
\hline \multirow{2}{*}{ Groups } & \multicolumn{2}{|c|}{ 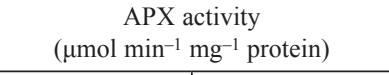 } & \multicolumn{2}{|c|}{$\begin{array}{c}\text { MDA content } \\
\left(\mu \mathrm{mol} \mathrm{MDA} \mathrm{g}{ }^{-1} \mathrm{FW}\right)\end{array}$} \\
\hline & $\operatorname{AsA}(-)$ & AsA (+) & $\operatorname{AsA}(-)$ & AsA (+) \\
\hline Control (0) & $\mathrm{B} 0.32 \pm 0.01^{\mathrm{f}}$ & $\mathrm{A} 0.71 \pm 0.01^{\mathrm{f}}$ & $\mathrm{A} 3.70 \pm 0.1^{\mathrm{f}}$ & $\mathrm{B} 2.53 \pm 0.2^{\mathrm{e}}$ \\
\hline $8 \mathrm{mM}$ pendimethalin & $\mathrm{B} 0.51 \pm 0.02 \mathrm{e}$ & $\mathrm{A} 0.98 \pm 0.02^{\mathrm{cd}}$ & $\mathrm{A} 4.01 \pm 0.2^{\mathrm{e}}$ & $\mathrm{B} 2.74 \pm 0.1^{\mathrm{e}}$ \\
\hline $16 \mathrm{mM}$ pendimethalin & $\mathrm{A} 1.02 \pm 0.01^{\mathrm{b}}$ & $\mathrm{A} 1.01 \pm 0.01^{\mathrm{c}}$ & $\mathrm{A} 4.30 \pm 0.1 \mathrm{e}$ & $\mathrm{B} 3.01 \pm 0.1^{\mathrm{cd}}$ \\
\hline $32 \mathrm{mM}$ pendimethalin & $\mathrm{A} 1.01 \pm 0.01^{\mathrm{b}}$ & $\mathrm{A} 1.03 \pm 0.01^{\mathrm{c}}$ & A6. $12 \pm 0.3^{b}$ & B3. $44 \pm 0.1^{\mathrm{c}}$ \\
\hline $50 \mathrm{mM} \mathrm{NaCl}$ & $\mathrm{B} 0.72 \pm 0.01^{\mathrm{d}}$ & $\mathrm{A} 0.80 \pm 0.01^{\mathrm{e}}$ & A $3.99 \pm 0.1^{\mathrm{f}}$ & B3.19 $\pm 0.2^{\mathrm{c}}$ \\
\hline $\begin{array}{l}50 \mathrm{mM} \mathrm{NaCl}+8 \mathrm{mM} \\
\text { pendimethalin }\end{array}$ & $\mathrm{B} 0.93 \pm 0.01^{\mathrm{c}}$ & $\mathrm{A} 1.28 \pm 0.02^{\mathrm{b}}$ & $\mathrm{A} 4.71 \pm 0.2^{\mathrm{d}}$ & $\mathrm{B} 3.98 \pm 0.1^{\mathrm{b}}$ \\
\hline $\begin{array}{l}50 \mathrm{mM} \mathrm{NaCl}+16 \mathrm{mM} \\
\text { pendimethalin }\end{array}$ & $\mathrm{B} 1.15 \pm 0.01^{\mathrm{a}}$ & $\mathrm{A} 1.71 \pm 0.03^{\mathrm{a}}$ & $\mathrm{A} 5.25 \pm 0.1^{\mathrm{c}}$ & $\mathrm{B} 4.22 \pm 0.1^{\mathrm{a}}$ \\
\hline $\begin{array}{l}50 \mathrm{mM} \mathrm{NaCl}+32 \mathrm{mM} \\
\text { pendimethalin }\end{array}$ & B0.90 $\pm 0.01^{\mathrm{c}}$ & $\mathrm{A} 0.95 \pm 0.01^{\mathrm{d}}$ & $\mathrm{A} 10.35 \pm 0.3^{\mathrm{a}}$ & $\mathrm{B} 4.25 \pm 0.2^{\mathrm{a}}$ \\
\hline
\end{tabular}

The different lower-case letters marked groups are significantly different from each other $(p<0.05)$ among different concentration of $\mathrm{NaCl}$ and pendimethalin according to Duncan's test. The different capital-case letters mark significant difference between the AsA $(+)$ and AsA $(-)$ samples $(p<0.05)$ of each concentration (of control and stress groups) according to independent samples " $t$ "--test.

treated with AsA was found in the $50 \mathrm{mM} \mathrm{NaCl}+16 \mathrm{mM}$ pendimethalin treated group as $1.71 \mu \mathrm{mol} \mathrm{min}^{-1} \mathrm{mg}^{-1}$ protein. Exogenous AsA treatment increased the APX activity both in control and stressed groups $(p<0.05)$ (Table 4$)$.

\section{MDA content}

The MDA content increased in the plants, regardless of AsA treatment, in the stress groups compared to the control groups $(p<0.05)$. The highest MDA content for the plants not pre-treated with AsA was found in the $50 \mathrm{mM} \mathrm{NaCl}+32 \mathrm{mM}$ pendimethalin treated group as $10.35 \mu \mathrm{mol} \mathrm{MDA} \mathrm{g}{ }^{-1} \mathrm{FW}$. Exogenous AsA treatment decreased the MDA content in the control and stressed groups $(p<0.05)$ (Table 4$)$.

\section{DISCUSSION}

Plant growth and development are affected by the environment [18]. Abiotic stresses, such as drought, salinity, cold, heat and chemical pollution are, often interconnected and lead to cellular damage and secondary stresses, such as osmotic and oxidative stress [42]. 
It has been shown by various studies that total the chlorophyll content is reduced in plants exposed to stress $[22,29,37]$. Our study has shown that, compared to herbicide stress, chlorophyll content is affected more by salt stress. In addition, reduction in chlorophyll content is more pronounced on plants exposed to stress simultaneously (Table 1).

Santos [37] has reported that chlorophyll content reduces at sunflower exposed to salt stress and he related this decrease with the chloropyllase enzyme activity change and the reduction in accumulation of 5-aminolaevunilic acid. Our study showed that exogenous AsA treatment increased total chlorophyll content in control and stress groups (Table 1). Similar to our findings, Khan et al. [24] have reported that foliar AsA treatment of sunflower exposed to salt stress increased total chlorophyll content on leaves.

Carotenoids are non-enzymatic antioxidants protecting plants from oxidative damage [26]. Sairam et al. [36] have shown that carotenoid content decreased in wheat depending on salt stress, while Kaya and Yiğit [23] have found that carotenoid content was reduced in sunflower depending on herbicide treatment. The present study showed that carotenoid content decreased in stress groups compared to control, whereas exogenous AsA treatment increased carotenoid content (Table 1). AsA plays an important role by participating in scavenging reaction of chloroplast from $\mathrm{H}_{2} \mathrm{O}_{2}$ or by acting as a cofactor for violaxanthin de-epoxidase [5]. In our study, the increase in total chlorophyll and carotenoid contents might be related with the role of the AsA in photosynthesis.

While AsA and GSH play a protective role against oxidative stress, they are also related with plant growth and control of cell cycle [35]. Our findings showed that both AsA and GSH contents increased in all stress groups compared to control (Table 2). Increase of both AsA and GSH amounts under stress might be related with the antioxidant characteristics of these compounds. Exogenous AsA treatment induced the response against stress by increasing the contents of AsA and GSH, which are the compounds involved in the ascorbate-glutation pathway. In addition, increase of endogenous AsA content in groups treated with exogenous AsA might be an indication of the transfer of AsA, that is applied to seed, to the inner tissues of developing plant.

AsA-GSH pathway in plants is important to create response against oxidative stress and it was shown by studies performed using mutant and transgenic plants that this pathway plays an important role for plant protection against stress [40]. APX and GR are two significant enzymes of ascorbate-glutathione cycle. APX utilizes AsA as electron donor and functions by reducing $\mathrm{H}_{2} \mathrm{O}_{2}$ [39]. APX activity might change when plants are exposed to different stresses. For example, Kaya and Yiğit [23] found that APX activity reduced at sunflower exposed to flurochloridon. Kostopoulou et al. [25] reported that APX activity increased in response to salt stress in Citrus aurantium plant. Our study showed that APX activity increased in all stress groups compared to control (Table 4). GR plays a major role in cell defense against oxidative stress. It efficiently maintains the reduced pool of GSH [14]. GST together with xenobiotic substances catalyzes the conjugation of GSH and plays an important role in 
detoxification [31]. Studies already exist showing that GST and GR activities change at sunflower exposed to different stresses [13, 14, 23, 44]. In the present study, GST and GR enzyme activities were shown to be increased all stress groups, compared to control. Treatment with both stress factors simultaneously induced a general increase of all antioxidant enzyme activities investigated (Table 3). It was shown that exogenous AsA treatment enhanced both GST activities that play a role on xenobiotic detoxification and APX and GR activities that are important compounds of ascorbateglutation pathway. This increase might be related with the induction of stress response due to the effect of AsA on antioxidant system.

The last product of lipid peroxidation, MDA, is an important indicator of oxidative stress [32]. There are reports showing that MDA contents increased at sunflower when treated with salt stress [3] and herbicide stress [23]. Similar to these findings, our study revealed that MDA content was increased at all groups exposed to stress, compared to control and this increase is more significant in groups simultaneously exposed to both stress factors. Exogenous AsA treatment reduced the MDA content of all groups (Table 4). Similar to our findings, Zhang and Kirkham [44] described that increase in MDA content at sunflower exposed to drought was inhibited by ascorbic acid and stated that this result is due to antioxidant characteristic of AsA and it can directly scavenge the radicals [44].

The findings of our study can be summarized as follows. At plants exposed to salt or herbicide stress, chlorophyll content decreases, MDA content increases, antioxidant defense responses develop. When the stresses are treated simultaneously, the aforementioned changes are more pronounced. Exogenous treatment with AsA, which is a non-enzymatic antioxidant, reduced the negative effects of stress on the parameters investigated. Plants are exposed to numerous stresses simultaneously at their natural environment. Therefore, the results of our study suggest that exogenous AsA (vitamin C) treatment on cultivated plants might improve their stress tolerance.

\section{REFERENCES}

1. Abbasi, M., Fakhani, E. (2015) Role of salicylic acid and ascorbic acid in the alleviation of salinity stres in wheat (Triticum aestivum L.) JBES 6, 107-113.

2. Akerboom, T. P. M., Sies, H. (1981) Assay of glutathione, glutathione disulfide and glutathione mixed disulfide in biological samples, In: Jakoby, W. B. (ed.), Methods in Enzymology 77, Academic Press, New York, pp. 373-382.

3. Akram, N. A., Ashraf, M., Al-Qurainy, F. (2012) Aminolevulinic acid-induced changes in some key physiological attributes and activities of antioxidant enzymes in sunflower (Helianthus annuus L.) plants under saline regimes. Sci. Hortic. 142, 143-148.

4. Andrews, C. J. (2005) Purifcation and characterisation of a family of glutathione transferases with roles in herbicide detoxifcation in soybean (Glycine max L.); selective enhancement by herbicides and herbicide safeners. Pestic. Biochem. Phys. 82, 205-219.

5. Anjum, N. A., Gill, S. S., Gill, R., Hasanuzzaman, M., Duarte, A. C., Pereira, E., Ahmad, I., Tuteja, R., Tuteja, N. (2014) Metal/metalloid stress tolerance in plants: role of ascorbate, its redox couple, and associated enzymes. Protoplasma 251, 1265-1283.

6. Appleby, A., Valverde, B. (1989) Behavior of dinitroaniline herbicides in plants. Weed Technol. 3, 198-206. 
7. Bradford, M. M. (1976) A rapid and sensitive method for the quantitation of microgram quantities of protein utilizing the principle of protein-dye binding. Anal. Biochem. 72, 248-254.

8. Bybordi, A. (2012) Effect of ascorbic acid and silicium on photosynthesis, antioxidant enzyme activity, and fatty acid contents in canola exposure to salt stress. JIA 11, 1610-1620.

9. Carlberg, I., Mannervik, B. (1985) Glutathione reductase. Method. Enzymol. 113, 484-490.

10. Çulha, Ş., Çakırlar, H. (2011) The effect of salinity on plants and salt tolerance mechanisms. AKU-J. Sci. Eng. 11, 11-34.

11. De-Kok, L., Graham, M. (1980) Levels of pigments, soluble proteins, amino acids and sulfhydryl compounds in foliar tissue of Arabidopsis thaliana during dark induced and natural senescence. Plant Physiol. Biochem. 27, 133-142.

12. Duncan, D. B. (1955) Multiple range and multiple F tests biometrics. IBS 11, 1-42.

13. Ebrahimian, E., Bybordi, A. (2011) Influence of different proportion of nitrate, ammonium and silicium on activity of antioxidant enzymes and some physiological traits in sunflower under conditions of salt stress. JFAE 9, 1052-1058.

14. Elloumi, N., Zouari, M., Chaari, L., Abdallah, F. B., Woodward, S., Kallel, M. (2015) Effect of phosphogypsum on growth, physiology, and the antioxidative defense system in sunflower seedlings. Environ. Sci. Pollut. 22, 14829-14840.

15. Gill, S. S., Anjum, N. A., Hasanuzzaman, M., Gill, R., Trivedi, D. K., Ahmad, I., Pereira, E., Tuteja, N. (2013) Glutathione and glutathione reductase: A boon in disguise for plant abiotic stress defense operations. Plant Physiol. Biochem. 70, 204-212.

16. Gill, S. S., Tuteja, N. (2010) Reactive oxygen species and antioxidant machinery in abiotic stress tolerance in crop plants. Plant Physiol. Biochem. 48, 909-930.

17. Habig, W. H., Pabst, M. J., Jakoby, W. B. (1974) The first enzymatic step in mercapturic acid formation Glutathion S-Transferases. J. Biol. Chem. 249, 7130-7139.

18. Haferkamp, M. R. (1988) Environmental factors affecting plant productivity. Achieving efficient use of rangeland resources. In: White, R. S., Short, R. E. (ed.), Fourth Keog Research Symposium. Montana Agr. Exp. Sta. Bozeman. p. 132.

19. Heath, R. L., Packer, L. (1968) Photoperoxidation in isolated chloroplast, I. Kinetics stoichiometry of fatty acid peroxidation. Arch. Biochem. Biophys. 125, 180-198.

20. Jabeen, N., Ahmad, R. (2013) The activity of antioxidant enzymes in response to salt stress in safflower (Carthamus tinctorius L.) and sunflower (Helianthus annuus L.) seedlings raised from seed treated with chitosan. J. Sci. Food Agr. 93, 1699-1705.

21. Kalefetoğlu, T., Ekmekçi, Y. (2005) The effects of drought on plants and tolerance mechanisms. GUJS $18,723-740$

22. Kaya, A., Doganlar, Z. B. (2016) Exogenous jasmonic acid induces stress tolerance in tobacco (Nicotiana tabaccum) exposed to imazapic. Ecotox. Environ. Safe 124, 470-479.

23. Kaya, A., Yiğit, E. (2014) The physiological and biochemical effects of salicylic acid on sunflowers (Helianthus annuus) exposed to flurochloridone. Ecotox. Environ. Safe 106, 232-238.

24. Khan, A., Lang, I., Amjid, M., Shah, A., Ahmad, I., Nawaz, H. (2013) Inducing salt tolerance on growth and yield of sunflower by appliying different levels of ascorbic acid. J. Plant Nutr. 36, $1180-1190$.

25. Kostopoulou, Z., Therios, I., Roumeliotis, E., Kanellis, A. K., Molassiotis, A. (2015) Melatonin combined with ascorbic acid provides salt adaptation in Citrus aurantium L. seedlings. Plant Physiol. Biochem. 86, 155-165.

26. Li, G., Wan, S., Zhou, J., Yang, Z., Qin, P. (2010) Leaf chlorophyll fluorescence, hyperspectral reflectance, pigments content, malondialdehyde and proline accumulation responses of castor bean (Ricinus communis L.) seedlings to salt stress levels. Ind. Crop. Prod. 31, 13-19.

27. Lichtenthaler, K., Welburn, A. R. (1983) Determination of total carotenoids and chlorophylls a and b of leaf extracts in different solvents. Biochemical Society Transactions, 603rd Meeting, Liverpool, pp. 591-592.

28. Liu, J., Wang, W., Wang, L., Sun, Y. (2015) Exogenous melatonin improves seedling health index and drought tolerance in tomato. Plant Growth Regul. 77, 317-326. 
29. Mafakheri, A., Siosemardeh, A., Bahramnejad, B., Struik, P. C., Sohrabi, Y. (2010) Effect of drought stress on yield, proline and chlorophyll contents in three chickpea cultivars. AJCS 4, 580-585.

30. Mandal, S., Yadav, S., Yadav, S., Nema, R. K. (2009) Antioxidants: A review. J. Chem. Pharm. Res $1,102-104$.

31. Mitsou, K., Koulianou, A., Lambropoulou, D., Pappas, P., Albanis, T., Lekka, M. (2006) Growth rate effects, responses of antioxidant enzymes and metabolic fate of the herbicide propanil in the aquatic plant Lemna minor. Chemosphere 62, 275-284.

32. M.-Kalantari, K. H., Oloumi, H. (2005) Study the effects of $\mathrm{CdCl}_{2}$ on lipid peroxidation and antioxidant compounds content in Brassica napus. Iranian J. Sci. Technol. Trans. A, 29, 201-208.

33. Mukherjee, S. P., Choudhuri, M. A. (1983) Implication of water stress induced changes in the levels of endogenous ascorbic acid and hydrogen peroxide in Vigna seedlings. Physiol. Plantarum 58, $166-170$

34. Nakano, Y., Asada, K. (1981) Hydrogen peroxide is scavenged by ascorbate specific peroxidase in spinach chloroplasts. Plant Cell Physiol. 22, 867-880.

35. Potters, G., Gara, L. D., Asard, H., Horemans, N. (2002) Ascorbate and glutathione: guardians of the cell cycle, partners in crime? Plant Physiol. Biochem. 40, 537-548.

36. Sairam, R. K., Rao, K. V., Srivastava, G. C. (2002) Differential response of wheat genotypes to long term salinity stress in relation to oxidative stress, antioxidant activity and osmolyte concentration. Plant Sci. 163, 1037-1046.

37. Santos, C. V. (2004) Regulation of chlorophyll biosynthesis and degradation by salt stress in sunflower leaves. Sci. Hortic. 103, 93-99.

38. Sivaci, A., Kaya, A., Duman, S. (2014) Effects of ascorbic acid on some physiological changes of pepino (Solanum muriactum ait) under chilling stress. Acta Biol. Hung. 65, 305-318.

39. Shigeoka, S., Ishikawa, T., Tamoi, M., Miyagawa, Y., Takeda, T., Yabuta, Y., Yoshimura, K. (2002) Regulation and function of ascorbate peroxidase isoenzymes. J. Exp. Bot. 53, 1305-1319.

40. Smirnoff, N. (1996) The function of metabolism of ascorbic acid in plants. Ann. Bot. London 78, 661-669.

41. Sondhia, S. (2012) Dissipation of pendimethalin in soil and its residues in chickpea (Cicer arietinum 1.) under field conditions. B. Environ. Contam. Tox. 89, 1032-1036.

42. Wang W., Vinocur, B., Altman, A. (2003) Plant responses to drought, salinity and extreme temperatures towards genetic engineering for stress tolerance. Planta 218, 1-14.

43. Verma, K., Shekhawat, G. S., Sharma, A., Mehta, S. K., Sharma, V. (2008) Cadmium induced oxidative stress and changes in soluble and ionically bound cell wall peroxidase activities in roots of seedling and 3-4 leaf stage plants of Brassica juncea (L.) czern. Plant Cell Rep. 27, 1261-1269.

44. Zhang, J., Kirkham, M. B. (1996) Antioxidant responses to drought in sunflower and sorghum seedlings. New Phytol. 132, 361-373. 